\title{
Pemberian Biskuit Sandwich Meningkatkan Berat Badan Ibu Hamil Berisiko Kurang Energi Kronis
}

\author{
Rika Andriani, ${ }^{*}$ Martha Irene Kartasurya**, Sri Achadi Nugraheni** \\ * Sekolah Tinggi Kesehatan Meulaboh, \\ ** Fakultas Kesehatan Masyarakat, Universitas Diponegoro \\ Email: rika.andryani23@gmail
}

\begin{abstract}
Low Weight gain during pregnancy may result in low birth weight babies. The number of pregnant woments at risk of Protein Energy (PEM) in Tegal regency on 2016 was 18,7\%, increased from $6.5 \%$ in 2015. The supplementary feeding, in the form of sandwich biscuits is one of the government efforts to improve nutrition of pregnant womens. The purpose of this study is to analyze the effect of supplementary feeding program on weight gain of pregnant womens at risk of protein energi malnutrition. The study was a quasi-experimental research. The study population were all of the pregnant womens who were at risk of protein and energi malnutrion in Tegal Regency. The subjects were 51 PEM pregnant womens from the foor families who got supplementary feeding and 51 in control group. Data were collected through interviews using structured questionnaires, and measured weight gain. Weight gain were measured prior to supplementary feeding of the third trimester and shortly after delivery. Data were analyzed using, independent-test, and GLM (General Linier Model). The majority of respondents in the treatment group and control group were 20-35 years old. The last education respondents in the treatment group and control group most of the SMP graduates are 22 respondents. The increase in body weight of pregnant womens who were at risk of protein energi malnutrition in ttreatment group $(5.5 \pm$ $1.10 \mathrm{~kg})$ was higher than the control group $(4.9$ $\pm 0.93 \mathrm{~kg}$ ) with a $p$ value of 0.001 .

It was concluded that biscuit supplementary feeding may increase pregnant womens body
\end{abstract}

weight. It is suggested that during supplementary feeding, supervision and motivation to increase biscuit consumption are needed.

Key Word : mid upper arm circumference, protein and energi, malnutrition, supplementation feeding, weight gain

\section{PENDAHULUAN}

Pada masa kehamilan, pemenuhan gizi sangat dibutuhkan untuk pertumbuhan dan perkembangan janin. ${ }^{1}$ Ibu hamil dengan gizi kurang mempunyai kemungkinan lebih besar untuk melahirkan bayi dengan BBLR. ${ }^{2}$ Kematian bayi karena BBLR di Kabupaten Tegal mencapai $30,1 \%$.

Berdasarkan data Dinas Kesehatan angka ibu hamil KEK (Kurang Energi Kronis) sejak 5 tahun terakhir di Kabupaten Tegal meningkat dari 6,50\% tahun 2015 menjadi 18,7 \% pada tahun 2016. Data ibu hamil KEK tertinggi terdapat di wilayah Puskesmas Pagerbarang dengan persentase berkisar $26,95 \%$ dan yang terendah terdapat di Puskesmas Kaladawa yaitu $0,9 \%$. $^{3}$

Kurang Energi Kronis terjadi akibat ketidakseimbangan antara asupan untuk pemenuhan kebutuhan tubuh dengan pengeluaran energi. ${ }^{4}$ Energi yang dibutuhkan selama kehamilan sekitar $80.000 \mathrm{Kkal}$ atau membutuhkan tambahan 300 Kkal setiap harinya dan pada trimester I lebih sedikit kebutuhan energinya 
dibandingkan pada trimester II dan III. ${ }^{5}$ Salah satu upaya perbaikan gizi ibu hamil dan mencegah malnutrisi pada ibu hamil adalah dengan Pemberian Makanan Tambahan (PMT). Kegiatan pemberian makanan tambahan bagi ibu hamil bertujuan untuk menambah asupan gizi ibu hamil sehingga kebutuhan gizi selama hamil dapat terpenuhi. ${ }^{6}$ Pemberian Makanan Tambahan pada Ibu Hamil KEK merupakan program pemerintah guna meningkatkan gizi ibu hamil KEK. ${ }^{7}$ Jenis makanan tambahan yang diberikan adalah Biskuit Sandwich, merupakan salah satu jenis makanan tambahan ibu hamil yang terbuat dari terigu, lemak nabati tanpa hidrogenasi, gula, susu, telur, kacangkacangan, buah kering, diperkaya dengan vitamin dan mineral, dengan atau tanpa penambahan Bahan Tambahan Pangan (BTP) sesuai dengan ketentuan yang berlaku. ${ }^{8}$

Program pemberian makanan tambahan pada ibu hamil KEK di Kabupaten kota Tegal sudah dilaksanakan sejak tahun 2009 hingga sekarang. Untuk tahun anggaran 2016/2017, program ini dimulai sejak bulan agustus 2016 dengan jumlah sasaran ibu hamil KEK 979 sasaran. Jenis makanan yang didistribusikan di kabupaten Tegal adalah biskuit sandwich dengan, energi total 500 kkal, lemak $25 \mathrm{gr}$, protein 15 gram, karbohidrat 28 gr, Natrium 240 mg dengan lama pemberian 90 hari.

\section{METODE PENELITIAN}

Desain Penelitian ini menggunakan kuasi eksperimen dengan rancangan pre post test design with control group. Teknik pengambilan sampel dengan Metode purposive sampling, subjek penelitian 51 ibu hamil KEK Gakin dan 51 ibu hamil KEK non gakin. Penelitian ini dilakukan pada bulan juni-agustus 2017 di Kabupaten Tegal.

Data penelitian diperoleh dari wawancara dengan metode recall konsumsi makanan 2x24 jam dan penimbangan berat badan ibu hamil mengunakan timbangan injak digital dengan ketelitian $0,1 \mathrm{~kg}$ sebelum dan sesudah diberikan makanan tambahan.

Data penelitian terdiri atas variabel bebas (pemberian biskuit sandwich) dan variabel terikat (pertambahan berat badan ibu hamil), variabel perancu (TKE dan TKP). Data dianalisis dengan menggunakan uji Independent $t$ test untuk menganalisis perbedaan pertambahan berat badan, TKE dan TKP pada kelompok perlakuan dan kontrol. Selanjutnya juga diuji multivariat menggunakan General Linier Model.

\section{HASIL DAN PEMBAHASAN}

Sebagian besar responden pada kelompok perlakuan dan kelompok kontrol berumur 20-35 tahun. Pendidikan terakhir responden pada kelompok perlakuan dan kelompok kontrol sebagian besar lulusan SMP yaitu 22 (43,1 \%). Responden pada kelompok kontrol dan kelompok kontrol sebagian besar pekerjaannya sebagai ibu rumah tangga. Sebagian besar paritas pada kelompok perlakuan dan kontrol < 2 yaitu $42(82,4$ $\%$ ) orang, proporsi Primigravida dan multigravida pada kelompok perlakuan dan kontrol seimbang. Pendapatan ibu hamil berisiko KEK sebagian besar di atas UMR pada kelompok kontrol yaitu 41 $(80,4 \%)$ sedangkan kelompok perlakuan hanya 25 orang $(49,0 \%)$. Karakteristik responden selengkapnya dapat dilihat pada Tabel 1

\section{Tabel 1 Karakteristik Responden}


Tabel 1 Karakteristik Responden

\begin{tabular}{|c|c|c|c|c|}
\hline \multirow{2}{*}{ Variabel } & \multicolumn{2}{|c|}{ Kelompok Pelakuan } & \multicolumn{2}{|c|}{ Kelompok Kontrol } \\
\hline & $\mathbf{F}$ & $\%$ & $\mathbf{F}$ & $\%$ \\
\hline \multicolumn{5}{|l|}{$\overline{\text { Umur }}$} \\
\hline$<20$ & 4 & 7,8 & 2 & 3,9 \\
\hline $20-35$ & 43 & 84,3 & 47 & 92,2 \\
\hline$>35$ & 4 & 7,8 & 2 & 3,9 \\
\hline \multicolumn{5}{|l|}{ Pendidikan } \\
\hline $\mathrm{SD}$ & 14 & 27,5 & 15 & 29,4 \\
\hline SMP & 22 & 43,1 & 16 & 31,4 \\
\hline Tamat SMA & 14 & 27,5 & 14 & 27,5 \\
\hline Perguruan Tinggi & 1 & 2,0 & 6 & 11,8 \\
\hline \multicolumn{5}{|l|}{ Pekerjaan } \\
\hline IRT & 49 & 96,1 & 43 & 84,3 \\
\hline PNS & 0 & 0,0 & 2 & 3,9 \\
\hline Buruh & 2 & 3,9 & 0 & 0,0 \\
\hline Swasta & 0 & 0,0 & 6 & 11,8 \\
\hline \multicolumn{5}{|l|}{ Paritas } \\
\hline$<2$ & 42 & 82,4 & 44 & 86,3 \\
\hline $2-3$ & 9 & 17,6 & 7 & 13,7 \\
\hline \multicolumn{5}{|l|}{ Gravida } \\
\hline Primigravida & 25 & 49,0 & 25 & 49,0 \\
\hline Multigravida & 26 & 51,0 & 26 & 51,0 \\
\hline \multicolumn{5}{|l|}{ Pendapatan } \\
\hline > UMR & 25 & 49,0 & 41 & 80,4 \\
\hline$<\mathrm{UMR}$ & 26 & 51,0 & 10 & 19,6 \\
\hline
\end{tabular}

Tingkat Kecukupan Energi (TKE)

Rata-rata TKE pada kelompok kontrol lebih tinggi dibandingkan kelompok perlakuan, apabila biskuit belum dihitung sebgai asupan makanan. Hasil uji analisis Independent $t$ test dengan $\mathrm{p}=0,001$.

Tingkat kecukupan energi pada kelompok perlakuan lebih tinggi jika dibandingkan dengan kelompok kontrol bila biskuit sandwich dihitung sebagai asupan makanan. Dari hasil analisis menggunakan independent $t$ test didapat $\mathrm{p}$ value 0,001 .

\section{Tingkat Kecukupan Protein (TKP)}

Rata-rata tingkat kecukupan protein sebelum dan sesudah diberikan makanan tambahan lebih tinggi pada kelompok perlakuan dibandingkan kelompok kontrol, bila biskuit sandwich dihitung sebagai asupan makanan dengan $\mathrm{p}=0,001$.

Setelah diberikan makanan tambahan tingkat kecukupan protein meningkat pada kelompok perlakuan, TKP pada kelompok perlakuan lebih tinggi dibandingkan kelompok kontrol. Data ini dianalisis dengan dimasukkan dosis biskuit sandwich setelah diuji beda ${ }^{7}$

dengan analisis independent $t$ test didapatkan $p$ value 0,001 .

Rata-rata tingkat kecukupan energi setelah ditambah dosis biskuit pada kelompok perlakuan lebih tinggi dibandingkan kontrol dengan $\mathrm{P}$ value 0,001 . (Gambar 2)

Asupan energi, protein, lemak dan karbohidrat memiliki pengaruh besar terhadap pertumbuhan dan perkembangan janin. ${ }^{9}$ Selama masa kehamilan ibu hamil 
membutuhkan makronutrien untuk memenuhi perubahan metabolik, fisiologi selama kehamilan dan pertumbuhan janin dalam kandungan. ${ }^{10,11}$ Nutrien yang sangat dibutuhkan oleh tubuh dan menjadi sumber utama untuk tubuh adalah energi yang berfungsi untuk mempertahankan berbagai fungsi tubuh seperti sirkulasi dan sintesis protein. ${ }^{12}$ Tambahan asupan energi yang dibutuhkan ibu hamil pada trimester I sebesar $180 \mathrm{kal}$, trimester II dan III $300 \mathrm{kal}$ sedangkan protein sebesar 17 gram untuk semua usia kehamilan. Pemberian suplementasi energi pada ibu selama kehamilan sebesar 300-850 kkal/hari. ${ }^{13,14,15}$

Energi sangat berperan penting untuk kesehatan ibu hamil serta dapat mempengaruhi berat badan lahir. Asupan selama kehamilan kebutuhannya tidak sama dengan sebelum kehamilan berdasarkan angka kecukupan gizi (AKG) tahun 2013 ibu hamil memerlukan asupan energi 300 kkal perhari. Penambahan protein 20 gr/hari, lemak $10 \mathrm{gr} /$ hari dan karbohidrat 40 gr/hari. ${ }^{16}$

Rata-rata tingkat kecukupan protein baik sebelum maupun setelah ditambah dengan biskuit sandwich pada kelompok perlakuan lebih tinggi dibandingkan kelompok kontrol dengan $\mathrm{p}=0,001$

Asupan protein penting untuk ibu hamil untuk proses pertumbuhan dan proses embriogenesis janin agar bayi yang dilahirkan normal. Asupan yang kurang pada ibu hamil dapat berdampak pada gangguan pertumbuhan janin sehingga bayi lahir dalam kondisi berat lahir rendah. Jika asuupan energi dan protein berlebihan dapat menghambat plasenta dan pertumbuhan janin sehingga dapat meningkatkan kematian janin. ${ }^{15}$

\section{Pertambahan Berat Badan Ibu Hamil Berisiko KEK}

Rata-rata pertambahan berat badan ibu hamil berisiko KEK pada kelompok perlakuan lebih tinggi dibandingkan kelompok kontrol setelah dilakukan uji analisis Independent Test yaitu $\mathrm{p}<0,05$. Ini menunjukkan biskuit sandwich dapat meningkatkan berat badan ibu hamil berisiko KEK (gambar 5 ).

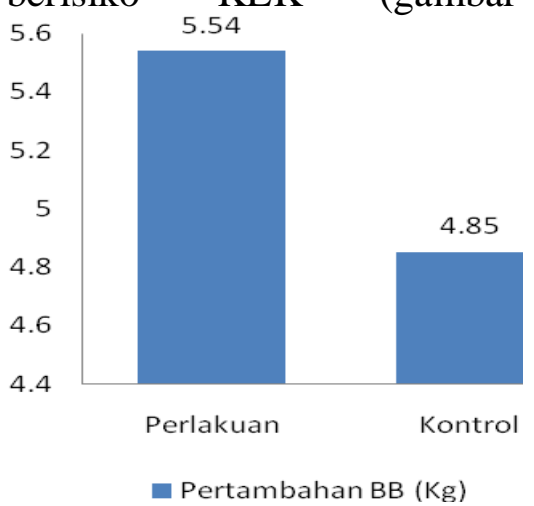

Gambar 1. Pertambahan Berat Badan Ibu Hamil Berisiko Kurang Energi Kronis

Ada pengaruh pemberian makanan tambahan terhadap peningkatan berat badan ibu hamil KEK. Setelah dikontrol dengan TKE ibu hamil kurang energi kronis. Diperoleh hasil uji multivariat $\mathrm{p}=0,001$ ( $\mathrm{p}$ $<0,05)$ tabel 2.

Tabel 2 Uji Multivariat Pertambahan

Berat Badan dikontrol dengan

TKE

\begin{tabular}{lccc}
\hline \multicolumn{1}{c}{ Variabel } & \multicolumn{2}{c}{ Kelompok } & $\mathrm{p}$ \\
& $\begin{array}{c}\text { Perlakua } \\
\mathrm{n}\end{array}$ & $\begin{array}{c}\text { Kontro } \\
\mathrm{l}\end{array}$ \\
\hline $\begin{array}{l}\text { Pertambaha } \\
\mathrm{n} \text { BB (kg) } \\
\text { Rata-rata }\end{array}$ & 5,865 & 4,857 & 0,00 \\
& & & \\
$\quad$ Standar & 0,174 & 0,141 & \\
$\quad$ Error & & & \\
\hline $\begin{array}{l}\text { Pemberian biskuit sandwich berpengaruh } \\
\text { terhadap peningkatan berat badan ibu hamil } \\
\text { kurang energi kronis setelah dikontrol } \\
\text { dengan TKE ibu hamil (Tabel 2). }\end{array}$
\end{tabular}

Tabel 3 Pertambahan berat badan Ibu hamil KEK setelah dikontrol dengan variabel TKP

\begin{tabular}{lccc}
\hline \multicolumn{1}{c}{ Variabel } & \multicolumn{2}{c}{ Kelompok } & P \\
& Perlakuan & Kontrol & \\
\hline Pertambahan & & & \\
BB (kg) & & & \\
Rata-rata & 5,865 & 4,857 & 0,001 \\
Standar & 0,174 & 0,141 & \\
$\quad$ Error & & & \\
\hline
\end{tabular}


Setelah dikontrol dengan TKP biskuit sandwich berpengaruh terhadap pertambahan berat badan ibu hamil berisiko KEK dengan $\mathrm{p}$ value 0,001 (Tabel 3).

Rata-rata peningkatan berat badan pada kelompok perlakuan lebih tinggi dibandingkan kelompok kontrol. Setelah dilakukan uji beda dengan analisisis independent $t$ test terdapat perbedaan peningkatan berat badan dengan $p$ value 0,001 ( Gambar 5).

Penelitian ini sejalan dengan penelitian yang dilakukan oleh Andradewi, makanan tambahan yang diberikan bahan dasar pangan lokal dengan kandungan energi 474,75 kkal dan protein 18,4 gram. Dari hasil penelitian tersebut menunjukkan bahwa ada peningkatan berat badan ibu hamil KEK setelah pemberian biskuit antara kelompok yang tidak mendapatkan makanan tambahan dan yang mendapatkan makanan tambahan. Rata-rata kenaikan berat badan pada kelompok perlakuan $5,80 \pm 2,007 \mathrm{~kg}$ sedangkan kelompok kontrol hanya $3,13 \pm 1,767 \mathrm{~kg} .^{17}$

Selama kehamilan ibu membutuhkan asupan makanan seimbang dari berbagai asupan makanan dalam jumlah proporsi untuk memenuhi kebutuhan gizi. Asupan makanan yang tidak seimbang akan penyebabkan ketidakseimbangan zat gizi. ${ }^{18}$

Di negara maju pertambahan berat badan selama hamil sekitar 10 - $12 \mathrm{~kg}$. Pada trimester I pertambahan kurang dari $1 \mathrm{~kg}$, trimester II sekitar $3 \mathrm{~kg}$, dan trimester III sekitar $6 \mathrm{~kg}$. Pertambahan berat badan ini juga dapat digunakan untuk memantau pertumbuhan janin. Pertambahan berat badan ibu hanya 7-8 kg dapat berakibat bayi lahir tidak normal atau berat bayi lahir rendah. ${ }^{19}$ Hal ini juga ditunjukkan oleh hasil penelitian yang dilakukan oleh Fabela, 2015, penelitian tersebut menunjukkan bahwa ada hubungan pertambahan berat badan ibu dengan kejadian berat bayi lahir rendah. ${ }^{20}$ Pemberian makanan tambahan merupakan salah satu upaya yang dilakukan pemerintah untuk meningkatkan status gizi ibu hamil berisiko KEK. Jenis makanan tambahan yang diberikan adalah biskuit sandwich dengan takaran saji 100 gram jumlah sajian perkemasan energi totalnya 500 kkal energi dan 15 gram protein. Dari hasil penelitian ini terbukti ibu hamil beresiko KEK yang mengkonsumsi makanan tambahan selama 90 hari pada trimester III dapat meningkatkan berat badan walaupun peningkatan berat badannya masih dibawah $6 \mathrm{~kg}$.

\section{KESIMPULAN}

Pemberian Biskuit sandwich selama 90 hari pada ibu hamil berisiko kurang energi kronis (KEK) trimester III dapat meningkatkan pertambahan berat badan selama hamil.

\section{UCAPAN TERIMA KASIH}

Atas nama peneliti kami mengucapkan beribu terima kasih kepada Pimpinan dan Staf Dinas Kesehatan Kabupaten Tegal yang telah memberikan kesempatan kepada kami untuk melakukan penelitian di wilayah ini. Serta tidak lupa terima kasih yang mendalam pada seluruh responden yang telah bersedia mendukung pelaksanaan penelitian ini sehingga kami dapat selesai sesuai rencana.

\section{DAFTAR PUSTAKA}

1. Info Datin, Situasi gizi di Indonesia. Kementerian Kesehatan RI; 2016

2. Kemenkes RI, Profil Kesehatan. 2013 http://depkes.go.id

3. Dinkes Kota Tegal. Profil Kesehatan Kota Tegal 2015.Tegal: Dinkes Kota;2015

4. Rahmaniar, Andi. 2013. Faktor-faktor yang berhubungan dengan kekurangan energi kronis pada ibuhamil di Tampa Padan, Kabupaten Mamuju, Sulawesi Barat 2013 Artikel Penelitian diunduh 25 desember 2016

5. World Health Organization (WHO). Energy and Protein Intake In Pregnancy WHO; 2003

6. Knudsen VK, Orozova B, Mikkelsen TB, Wolff S, Olsen SF. Major dietary 
pattern in pregnancy and fetal growth. Europe Journal of Clinical Nutrition. 2008;62:463-70.

7. Uswatun, Anna. Hubungan Lingkar Lengan Atas (LILA) Ibu Hamil dengan berat bayi baru lahir di RSUP Dr Soeradji Tirtonegoro Klaten . Artikel Penelitian Motoric, 2013 Vol. 8 nomor 16

8. keputusan Menteri Kesehatan Republik Indonesia, NOMOR: 899/Menkes/SK/X) 2009 Spesifikasi Teknis Makanan Tambahan Anak Balita 2-5 Tahun, Anak Usia Sekolah Dasar dan Ibu Hamil; 2009 di unduh 20 januari 2017

9. Almatsier S. Prinsip Dasar Ilmu Gizi. Jakarta: Gramedia Pustaka; 2011

10. Hurlock E. Perkembangan anak. Jakarta: Erlangga; 2006.

11. Barasi ME. At a glance ilmu Gizi. Jakarta: EMS; 2007.

12. Gambling, MC. Ardle. Nutrition requirment during pregnancy chapter I. Cambridge: United Kingdom University Press; 2010.

13. Khoiriah, Fabella. Hubungan Pertambahan berat badan ibu selama hamil dengan berat bayi lahir rendah di Puskesmas Kecamatan Metro Pusat. Artikel penelitian J Majority olume 4 nomor 32015 di unduh 15 september 2017.
14. Nugrahini EY dkk. 2014. Asupan Energi dan Protein setelah Program Pemberian Makanan Tambahan Pemulihan Ibu Hamil Kurang Energi Kronik di Puskesmas Kota Surabaya. IJEMC, Volume 1 No. 1, Desember 2014

http://www.ijemc.org/wpcontent/uploa ds/2015/01/5.pdf (di unduh 11 september 2017).

15. Fathonah, Siti. Gizi dan Kesehatan untuk Ibu Hamil. Jakarta: Erlangga; 2016.

16. Departemen Gizi dan Kesehatan Masyarakat Fakultas Kesehatan Masyarakat Universitas Indonesia. 2007. Gizi dan Kesehatan Masyarakat. PT Rajagrafindo Persada, Jakarta.

17. Candradewi. Pengaruh makanan tambahan terhadap peningkatan berat badan ibu hamil KEK diwilayah kerja Puskesmas Labuan Lombok, 2015; jurnal kesehatan Prima di unduh 11 januari 2017

18. Riyanto, A. 2004. Widya Karya Pangan Nasional dan Gizi. Jakarta.

19. Erna, F. Gizi dalam kesehatan Reproduksi. Jakarta: EGC; 2004

20. Badan Penelitian dan pengembangan Kesehatan 2007. Riset Kesehatan Dasar RISKESDAS) ;2007 